\title{
Luxúria e iconografia na escultura românica portuguesa
}

Joaquim Luís Costa

\section{OpenEdition}

Journals

\section{Edição electrónica}

URL: http://journals.openedition.org/medievalista/1489

DOI: 10.4000/medievalista.1489

ISSN: 1646-740X

\section{Editora}

Instituto de Estudos Medievais - FCSH-UNL

\section{Refêrencia eletrónica}

Joaquim Luís Costa, « Luxúria e iconografia na escultura românica portuguesa », Medievalista [Online], 17 | 2015, posto online no dia 01 junho 2015, consultado no dia 19 abril 2019. URL : http:// journals.openedition.org/medievalista/1489; DOI : 10.4000/medievalista.1489

\section{(C) IEM}




\section{Medievalısta onine}

Título: Luxúria e iconografia na escultura românica portuguesa

Autor(es): Joaquim Luís Costa

Universidade: Rota do Românico

Faculdade e Departamento / Unidade de Investigação: Centro de Estudos do

Românico e do Território

Código Postal: 4620-130

Cidade: Lousada

País: Portugal

Contacto: joaquim.costa@valsousa.pt

Fonte: Medievalista [Em linha]. Direc. José Mattoso. Lisboa: IEM.

Disponível em: http://www2.fcsh.unl.pt/iem/medievalista/

ISSN: 1646-740X

Data recepção do artigo: 19 de Março de 2014

Data aceitação do artigo: 14 de Novembro de 2014

\section{Resumo}

A luxúria na iconografia românica portuguesa - enquanto sinónimo de erotismo -, tem sido pouco abordada no panorama científico nacional. $\mathrm{O}$ presente artigo procura contribuir para este debate, analisando diversas áreas simbólicas e temáticas que podemos encontrar no bestiário medieval, na Bíblia, ou nas representações do ser humano e do mundo animal. A investigação levou-nos à conclusão de que a luxúria se encontra presente de norte a sul do país, apesar de ter maior incidência no norte, estando especialmente centrada na temática das sereias e onde se destaca o Mosteiro de Travanca por funcionar como polo irradiador, apresentando uma representação sexual algo contida. 
Palavras-chave: Arte românica; Escultura erótica; Luxúria; Iconografia; Portugal.

\section{Abstract}

The luxury on the Portuguese Romanesque iconography - as a synonym of eroticism -, has been little studied. The present article contributes to this debate by analyzing different symbolic and thematic areas that can be found on the Medieval Bestiary, on the Bible, on the human being and on the animal world representations. The investigation led us to the conclusion that the luxury can be found from the north to the south of the country, though more incident on the north, and especially focused on the mermaid theme. In this respect, the Travanca Monastery works as an irradiating center presenting sexual representations somehow repressed.

Keywords: Romanesque Art; Erotic Sculpture; Luxury; Iconography; Portugal. 


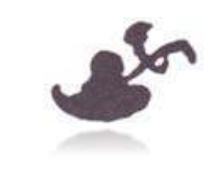

\title{
Luxúria e iconografia na escultura românica portuguesa
}

\author{
Joaquim Luís Costa
}

\section{A interpretação da luxúria}

A arte é entendida como uma extensão da vida humana, que o Homem utiliza como ato de criatividade e como modo de expressar estados de espírito ou o quotidiano. Como a religião integra as vivências de uma parte considerável dos seres humanos, esta não poderia ficar indiferente ao espírito artístico, usando-o para passar a sua mensagem de fé, especialmente na luta contra o pecado. Consequentemente, a luxúria - um dos sete pecados capitais, e neste caso em estudo, sinónimo de erotismo e sedução - teria de estar representada artisticamente.

Acontece que o erotismo foi visto ao longo dos milénios de diferentes prismas, levando a que a sua figuração, e portanto aceitação ou negação, variasse consoante os valores religiosos de cada civilização. Se remontarmos à Idade da Pedra Lascada, há 2.500 milhões de anos atrás, o erotismo era notório especialmente no culto à mulher grávida. A estatueta, em calcário com 11,1 cm de altura, da Vénus [ou Mulher] de Willendorf, é sinónimo deste culto, expresso nuns seios extremamente volumosos ${ }^{1}$.

No Antigo Egito politeísta, o ato sexual, para além de ser um momento erótico e de prazer, era também uma ação criadora da origem da vida. Os deuses amavam e faziam sexo, criando vínculos com os homens terrenos. Não era por isso estranho encontrar-se

\footnotetext{
${ }^{1}$ SERNA, Andrés - El romanico erotico: lujuria en los templos cristianos [Em linha]. S.1.: s.n., 2012, p. 2. [Consultado a 11.12.2013]. Disponível em: WWW:<URL:http://elcorreodelasmatas.blogspot.pt/2012/12/el-romanico-erotico-lujuria-en los.html>.
}

Medievalista online № 17। Janeiro - Junho 2015 C $\mathbb{E M}$ - Instituto de Estudos Me dieva is 3 www2.fc sh.unl.pt/ie m/me die va lista 
representações ousadas em túmulos ou pirâmides². Por seu turno, as civilizações clássicas também foram tolerantes com o sexo. Na Grécia representava-se a beleza e o ideal estético da perfeição. Os deuses Apolo, Zeus, Posídon eram geralmente representados nus. Já Roma seguiu, ou quase copiou, a arte helénica, encontrando-se numerosas cenas nas quais abundam a nudez, mostrando-a sem pudor $^{3}$, como mais um aspeto do quotidiano.

Se para o Homem clássico o corpo nu era motivo de orgulho, para os cristãos medievais seria sinónimo de pecado e, portanto, de vergonha e rejeição. Uma das características da Idade Média ocidental foi a instituição Igreja, que representava o sagrado e dominava o mundo de uma forma confessional. A Igreja confundia-se com a própria sociedade, que tudo envolvia desde o nascimento até à morte. O Além estava sempre presente nas vidas terrenas através dos méritos de Jesus Cristo, das obras dos Santos ou dos sacrifícios dos fiéis. Existia um centralismo eclesial que tudo dominava. Quando frei Álvaro Pais ${ }^{4}$ disse que os hispanos "são, entre os outros cristãos imundos, os que mais se entregam à luxúria e às fornicações" 5 , mais não fez do que constatar a necessidade de se lutar contra esse mal.

De facto, a condenação dos comportamentos sexuais foi uma prática corrente no catolicismo. A busca da salvação pedia a conversão do homem através da purificação do seu corpo. Não será assim de estranhar que a Igreja Católica defendesse a contenção sexual em todos os campos de atuação do Homem, mesmo dentro do casamento: as práticas sexuais deviam respeitar o calendário litúrgico, recomendava-se moderação nas posições admitidas durante o coito e condenava-se o que consideravam desvios sexuais (entre eles, a homossexualidade e a masturbação) ${ }^{6}$. A abstinência monástica era, deste modo, um modelo a seguir. Exemplo prático desta visão pode ser encontrado em finais do século XIV nos conselhos dados aos confessores, na forma como falariam do pecado

\footnotetext{
${ }^{2}$ Ibidem.

${ }^{3}$ Ibidem.

${ }^{4}$ Nasceu em 1270 em San Juan del Salnés, Pontevedra, foi frade franciscano e bispo de Silves a partir de 1334. Morreu em 1349, exilado em Sevilha. Cf. SOUZA, Armênia Maria - "A realeza cristã ibérica no Espelho dos reis de frei Álvaro Pais (séc. XIV)". in Dimensões. Vol. 26 (2011), p. 190.

5 OLIVEIRA, António Resende de - "A sexualidade". in MATTOSO, José (dir.) - História da vida privada em Portugal: a Idade Média. Vol. I. Lisboa: Temas e Debates, 2011, p. 333.

${ }^{6}$ Ibidem.
}

Medievalista online № 17। Janeiro - Junho 2015 (C) $\mathbb{E M}$ - Instituto de Estudos Medieva is 4 www2.fc sh.unl.pt/ie $\mathrm{m} / \mathrm{me}$ die va lista 
da luxúria, onde se incluíam os pecados sexuais: os confessores deviam colocar as questões de forma geral, sem entrar em grandes pormenores para evitar novos desvios ${ }^{7}$. Como expõe José Mattoso ${ }^{8}$, era necessário dominar, domesticar e esconder tudo aquilo que, por meio do corpo, soltava a natureza animal do Homem e trazia a desordem social.

Contudo, esta doutrina não impediu a representação artística. Pelo contrário. Foi um motivo adicional, uma forma de evidenciar os males do indivíduo. Ou seja, ao mesmo tempo que se procurava restringir estes atos, a Igreja Católica sabia que a sua representação pela arte poderia ser uma forma de controlar a mentalidade medieval. Por outras palavras, a arte românica ao serviço da religião ilustrava uma civilização em que o Cristo-Deus interrogava o Homem, ao mesmo tempo que o educava, sendo a Igreja a grande porta para esse mundo celeste que, através das esculturas, pretendia envolver os errantes da vida humana para que pudessem ascender aos céus. Neste ideal, a escultura românica tinha papel relevante, pois seria através dela que os fiéis se instruíam na fé e tomavam consciência de Deus e do temor ao Inferno ${ }^{9}$. Assim sendo, os programas iconográficos foram ao encontro de crenças, temores e sentimentos populares dos fiéis, incorporando elementos do seu imaginário, muitas vezes relacionados com a luta entre as forças do bem e do mal ou os vícios e as virtudes, conferindo a esta arte uma clara intenção moralizadora ${ }^{10}$.

Todavia, esta forma de encarar o problema só se aplicou a partir do século XII pois, até então, o uso da arte escultórica tinha sido desvalorizada porque era associada aos cultos pagãos ${ }^{11}$, sendo as imagens vistas como ídolos. Só esta maior abertura e tolerância por parte da Igreja é que permitiram a inclusão de imagens esculpidas nos espaços

\footnotetext{
${ }^{7}$ Ibidem, p. 335.

${ }^{8}$ MATTOSO, José - "O corpo, a saúde e a doença". in MATTOSO, José (dir.) - História da vida privada em Portugal: a Idade Média. Vol. I, Lisboa: Temas e Debates, 2011, p. 349.

${ }^{9}$ PACAUT, Marcel - "A Europa românica ou o tempo das primeiras sementeiras". in GRIMAL, Pierre et al. - História geral da Europa. Vol. I. Mem Martins: Europa-América, 1996, pp. 355-440.

${ }^{10}$ ALMEIDA, Carlos Aberto Ferreira de - História da arte em Portugal: o românico. Lisboa: Editorial Presença, 2001. p. 162 e SOUSA, Luís Correia de - "Iconografia musical na escultura Românica em Portugal". in Medievalista [Em linha]. $\mathrm{N}^{\mathrm{o}}$ 1, ano 1 (2005). p. 2. [Consultado a 11.12. 2013]. Disponível em: http://www2.fcsh.unl.pt/iem/medievalista/MEDIEVALISTA1/medievalista-iconografia.htm.

${ }^{11}$ Entre o século $\mathrm{V}$ e o século $\mathrm{X}$ a escultura de representação humana praticamente desapareceu devido à associação com a idolatria e o paganismo. Ver ROSAS, Lúcia - "A análise crítica". in SANTOS, Maria José Ferreira dos (coord.) - Igreja de S. Pedro de Abragão: redescobrir um templo românico. Penafiel: Museu Municipal de Penafiel, 2008, p. 24.
} 
religiosos. Para esta mudança de mentalidade muito contribuíram os monges de Cluny, porque viram nesta forma de expressão uma forte aliada na propagação da fé ${ }^{12}$.

A partir de então, começaram a surgir programas iconográficos para decoração dos espaços religiosos, baseados em temas bíblicos (Daniel na cova dos leões, o Leviatã, Jonas saindo da baleia ou a tentação de Adão e Eva), em textos clássicos (como a Psychomachia ${ }^{13}$ ) ou no bestiário (uso de animais e seres fantásticos como leões, sereias, dragões... monstros em geral), com a clara intenção de serem usados para fins narrativos e simbólicos ${ }^{14}$ ligados à luta entre o bem e o mal. Porém, estes não eram os únicos dois campos de inspiração. $\mathrm{O}$ simbolismo relativo às práticas quotidianas e ao destino do Homem também foram utilizados como fonte para expressar a necessidade de se caminhar para Deus. Neste contexto, é de referir a escultura moralizadora no combate aos vícios ou na luta da alma para se livrar das tentações da carne, procurando a castidade ${ }^{15}$. A representação de mulheres e homens em atitudes eróticas ou sexuais é disso um exemplo.

Interiorizando este espírito, os criadores românicos foram zelosos no estabelecimento de um esquema dual contrapondo Deus e o demónio, o bem e o mal, o pecado e a virtude, o prémio e o castigo. Esta imaginação dos escultores, favorecidos por um ambiente

\footnotetext{
${ }^{12}$ SOUSA, Luís Correia de - "Iconografia musical na escultura Românica em Portugal", p. 1.

${ }^{13}$ Ou Psicomaquia, em português, é um livro de poemas escrito pelo poeta romano cristão Prudêncio (século IV-V) sobre as sete batalhas da Alma para impor as virtudes aos vícios. Numa dessas batalhas temos a Castidade a lutar contra a Luxúria. Esta obra foi sucessivamente ilustrada por pintores e iluministas medievais e fonte de inspiração para os escultores românicos, que copiaram e imitaram as suas figuras. Ver RODRIGUES, Jorge - "A escultura românica". in PEREIRA, Paulo - História da arte portuguesa. Vol. I. Lisboa: Círculo de Leitores, 2006, p. 302.

14 VERMEERSCH, Paula Ferreira - "Considerações sobre representações fantásticas em capitéis românicos". in Unicamp - Instituto de Estudos da Linguagem [Em linha]. (1998) p.1. [Consultado a 22.12.2013]. Disponível em: http://www.unicamp.br/iel/site/alunos/publicacoes/textos/c00016.htm.

${ }^{15}$ RÉAU, Louis - Iconografía del arte cristiano: iconografía de la Biblia: Nuevo Testamento. Tomo I, vol. 2. Barcelona: Ediciones del Serbal, 2008, p. 212.
} 
cultural com elevados índices de analfabetismo ${ }^{16}$, fez da iconografia românica um autêntico museu de fantasia ${ }^{17}$.

A par desta abordagem, outras existem para justificar a luxúria nas igrejas. Uma delas sugere a irreverência por parte dos escultores românicos que viram na escultura uma forma de provocar o observador, sob a capa da representação do pecado ${ }^{18}$. Esta abordagem é corroborada por León Gómez ${ }^{19}$, pois considera que estas representações eram executadas por livre iniciativa dos artesãos, com um sentido burlesco ou de crítica social. Estas seriam feitas na periferia ${ }^{20}$ ou nas partes superiores das igrejas, sendo o local onde os artistas tinham maior liberdade de expressão ${ }^{21}$. Uma outra abordagem defendida por Andrés Serna considera que a fecundidade e o poder económico seriam motivos justificativos. Segundo o autor espanhol, vivia-se numa sociedade onde a fome e as guerras eram constantes. Logo, o erotismo pretenderia fomentar a procriação humana $^{22}$. Mas, como era um ato pecaminoso, as pessoas com medo do Inferno, sentiam-se na obrigação de pagarem tributos pelo pecado cometido ${ }^{23}$. Conclusão: quantas mais pessoas houvesse, mais católicos pecavam e mais tributos pagavam à Igreja.

Perante as três abordagens apresentadas, consideramos que a primeira será a mais consensual. De acentuar que estamos numa sociedade subjugada ao poder católico, com uma mentalidade bastante fechada e que seria pouco habitual que a Igreja pudesse dar

\footnotetext{
${ }^{16}$ A Igreja medieval tinha um problema de comunicação com os fiéis. Como a larga maioria da população vivia numa profunda ruralidade e não sabia ler e muito menos escrever, urgia a necessidade de se encontrar uma forma de passar a mensagem religiosa. Uma das soluções foi a pedra das igrejas. Sobre isto, de lembrar que séculos antes já o papa Gregório I, o Grande, (590-604), aconselhava os clérigos para pregarem através de imagens porque estas eram a escrita dos iletrados. Vemos assim o lado didático da sua representação. in LOPES, Hugo - "Os mosteiros medievais como edifícios de saber: A conquista do território pela implantação de conhecimento desde o século X ao século XII - O caso português como ilustração paradigmática". in Millenium: Revista do ISPV [Em linha]. Ano 8, no 27 (Abr. 2003) p.153. [Consultado a 08.11.2013]. Disponível em: http://www.ipv.pt/millenium/millenium27/20.htm .
}

17 MARTíN JIMÉNEZ, Carlos M. - Las mejores rutas por el románico de Palencia. Palencia: Deputación de Palencia, 2008. p. 43.

${ }^{18}$ RODRIGUES, Jorge - op. cit., p. 304.

${ }^{19}$ LEÓN GÓMEZ, Carmelo - "Rutas por el Románico de la comarca: el románico erótico". in Arevagos [Em linha]. No 40. El Burgo de Osma: Aprodebur, 2010, p. 4. [Consultado a 08.11.2013]. Disponível em: http://www.islabahia.com/aprodebur/Arevacos/40_enero2010/40romanico.htm.

${ }^{20}$ RODRIGUES, Jorge - op. cit., p. 296.

${ }^{21}$ LEÓN GÓMEZ, Carmelo - "Rutas por el Románico", p. 4.

${ }^{22}$ SERNA, Andrés - El romanico erotico: lujuria en los templos cristianos [Em linha]. S.1.: s.n., 2012, p. 9. [Consultado a 11.12.2013]. Disponível em: http://elcorreodelasmatas.blogspot.com.es/2012/12/elromanico-erotico-lujuria-en-los.html.

${ }^{23}$ Ibidem, pp. 9-10.

Medievalista online № 17 । Jane in - Junho 2015 @ $\mathbb{E} M$ - Instituto de Estudos Me dieva is 7 www2.fc sh.unl.p $\mathrm{t} / \mathrm{ie} \mathrm{m} / \mathrm{me}$ die va lista 
tanta liberdade aos mestres artesãos na Casa de Deus. Para mais, os escultores românicos não seriam muito letrados, nem teriam grande poder económico para poder influenciar. Ainda, teriam de estar sempre sujeitos às imposições dos encomendadores (ou seja, a Igreja).

\section{O estudo da luxúria em Portugal}

O estudo da escultura românica de aspeto luxurioso ainda se encontra num estado embrionário em Portugal, não havendo muitos estudos aprofundados sobre o tema. A investigadora Maria Leonor Botelho ${ }^{24}$, na sua tese de doutoramento, analisou, desde o século XIX até aos nossos dias, toda a documentação produzida sobre arte românica pelos mais eminentes investigadores portugueses e unicamente particularizou o autor António Coelho de Sousa Oliveira que, em 1965, publicou o artigo Temas Psicomáquicos na Escultura Românica Decorativa, onde apontava os "combates da alma”, manifestados através das lutas entre os vícios e as virtudes, entre o bem e o mal $^{25}$. Em 1986, Manuel Real num capítulo ${ }^{26}$ na obra Portugal Roman coordenada por Gerhard Graf, opina sobre a temática, mas numa análise global à escultura figurativa. Exemplo mais próximo da atualidade é Jorge Rodrigues ${ }^{27}$, que em vários estudos sobre arte românica dedica sub-capítulos aos vícios e virtudes.

Por regra, esta temática é referida no contexto geral de um imóvel religioso e não isoladamente. Existe a tendência para analisar no conjunto e não pormenorizar. Esta temática apresenta-se assim como marginal no estudo do românico português. Embora não mencione diretamente a escultura erótica, o escrito por Paulo Almeida Fernandes, em 2009, vem ao encontro deste sentimento de muito haver por fazer, quando afirma que existem áreas de estudo abandonadas no românico português:

"[...] a par da difusão de um modelo explicativo não-evolutivo do estilo contribuem para uma sensação enganosa: a de que o caminho científico está

\footnotetext{
${ }^{24}$ Ver BOTELHO, Maria Leonor - A historiografia da arquitectura da época românica em Portugal: 1870-2010. Lisboa: FCG/FCT, 2013.

${ }^{25}$ Ibidem, p. 253.

${ }^{26}$ Ver REAL, Manuel Luís - "La sculpture figurative dans l'art roman du Portugal". in GRAF, Gerhard Portugal Roman. Vol. I. Yonne: Zodiaque, 1986, pp. 33-75.

${ }^{27}$ Ver RODRIGUES, Jorge - "O mundo românico: séculos XI-XIII". in PEREIRA, Paulo - História da arte portuguesa. Vol. 2. Lisboa: Círculo de Leitores, 1995, pp. 130-135.
} 
percorrido na maior parte do seu trajecto, não restando grandes áreas de discussão e investigação, nem novas descobertas que justifiquem um renovado investimento. Este equívoco, reforçado em obras recentes que pouco trouxeram de novo, parece solidamente implantado, mas está longe de corresponder à realidade" 28 .

Contrariamente ao que se verifica em Portugal, o mesmo não acontece noutros países. Geograficamente, podemos encontrar a escultura sobre a luxúria um pouco por toda a Europa românica, desde a Alemanha, Itália, França, Inglaterra, Irlanda ${ }^{29}$ ou na vizinha Espanha. Por exemplo, neste último país, a abordagem encontra-se mais desenvolvida se comparada com a do nosso país. Andrés Serna ou León Gómez, já citados, são exemplos de investigadores que se debruçam sobre o tema. Simultaneamente, várias instituições têm-se dedicado a fomentar o mesmo assunto. Caso concreto é a Fundación Santa Maria la Real onde, no VII Curso de Iniciación al Románico e sob a temática Poder y seducción de la imagen românica, foi apresentada por Jaime Nuño González a comunicação Hacia una visión de la iconografia sexual: escenas procaces y figuras obscenas. Mais recentemente, o mesmo autor proferiu a conferência El Románico Erótico nesta mesma instituição.

Não obstante ser relativamente fácil encontrarmos este tipo de escultura por toda a Espanha, devemos salientar Palência, Burgos e Cantábria como regiões abonadas em erotismo. Em Palência temos a igreja de San Martín de Frómista ou o Mosteiro de Santa Maria La Real; em Burgos podemos indicar as igrejas da Inmaculada Concepción de Crespos, San Pedro de Tejada e de San Miguel de Cornezuela; na Cantábria, Villanueva de la Nía, San Martín de Elines ou San Pedro de Cervatos, são outros exemplos. De mencionar que a última igreja será um dos bastiões representativos da luxúria em imóveis românicos espanhóis.

Com este exemplo tão próximo, podemos parafrasear Paulo Fernandes quando escreve que "Portugal está, desta forma, bem longe das grandes conquistas feitas pela História da Arte além-fronteiras" 30 .

\footnotetext{
${ }^{28}$ FERNANDES, Paulo Almeida - "A escultura românica em Portugal: construções historiográficas e desafios actuais". in COLÓQUIO INTERNACIONAL DE HISTÓRIA DA ARTE - A escultura em Portugal da Idade Média ao início da Idade Contemporânea: história e património. Lisboa: Fundação das Casas da Fronteira e de Alorna, 2009, p. 27.

${ }^{29}$ SERNA, Andrés - op. cit., p. 7.

${ }^{30}$ FERNANDES, Paulo Almeida - "A escultura românica em Portugal", p. 33.
} 
Uma das possíveis razões para que a escultura erótica esteja mais estudada noutros países poderá encontrar-se na forma de investigar, optando-se pelo seu enquadramento numa análise geral a um imóvel ou no facto de se considerar um estudo acessório dentro do românico. Provavelmente, será esta última uma das hipóteses mais credíveis, se atestarmos que o próprio Réau também a desvaloriza quando a considera secundária se comparada com outras temáticas iconográficas ${ }^{31}$.

Posto isto, é intuito deste artigo analisar o emprego da temática da luxúria nos imóveis religiosos românicos, procurando demonstrar a sua relevância artística e, deste modo, incentivar mais estudos individualizados numa área pouco investigada em Portugal. Para ir ao encontro deste objetivo, a metodologia utilizada passou por fazer um levantamento, embora sem a intenção da exaustividade, das figurações escultóricas sob o ponto de vista da luxúria. A visita a imóveis românicos e o recurso a obras de referência foram os instrumentos utilizados para se fazer a recolha de dados que está expressa no ponto seguinte.

\section{A luxúria no românico português}

No nosso país, a escultura românica chegou com os monges de Cluny e estendeu-se do Minho ao Alentejo ${ }^{32}$, apresentando influências e soluções muito diversas. O Alto Minho foi bastante influenciado pela Galiza com os exemplos concretos de Longos Vales, Friestas, Paderne ou Orada. De recordar que a fronteira política entre Portugal e Galiza, materializada pelo Minho, não correspondia equitativamente a uma mesma fronteira eclesiástica, uma vez que este território pertenceu à diocese de Tui até $1381^{33}$.

Já o românico tardio do Vale do Sousa apresenta-se como uma miscelânea de influências de vários dialetos do românico como o bracarense, o portuense ou o

\footnotetext{
${ }^{31}$ RÉAU, Louis - Iconografía del arte cristiano: introducción general. Vol. 3. Barcelona: Ediciones del Serbal, 2008, p. 173.

${ }^{32}$ MARQUES, Marisa Costa - "O mundo do fantástico na arte românica e gótica em Portugal: o género diplomático 'notícia' na documentação medieval portuguesa (séculos X-XIII). Tese de Mestrado em História da Arte, apresentada à Faculdade de Ciências Sociais e Humanas da Universidade Nova de Lisboa em Julho de 2007". in Medievalista [Em linha]. $N^{\text {o }} 8$ (Jul. de 2010) p. 4. [Consultado a 08.11.2013]. Disponível em: http://www2.fcsh.unl.pt/iem/medievalista/MEDIEVALISTA8/marques8013.html.

${ }^{33}$ ROSAS, Lúcia (coord.) - Românico do Vale do Sousa. Lousada: VALSOUSA, 2008, p. 41.
} 
coimbrão, em que a Igreja do Mosteiro de Paço de Sousa (Penafiel) é o exemplo concreto do designado românico nacionalizado.

Por sua vez Coimbra, por razões históricas, cedo recebeu interferências vindas de França às quais se miscigenaram reportórios e técnicas próprias da arte moçárabe, que tinha antecedentes bem enraizados na região, criando uma linguagem decorativa muito original $^{34}$. Mas independentemente das suas origens e influências, a escultura estará ao serviço da religião ${ }^{35}$, sendo incorporada nos portais, com destaque para o tímpano pelo seu significado simbólico, no enquadramento das janelas e nos capitéis ${ }^{36}$. Especial ênfase foi colocada similarmente nos modilhões, isto porque a escultura nestes espaços conheceu, neste período, um notável desenvolvimento, integrando temas mais variados que os destinados a outras partes do edifício ${ }^{37}$, havendo segundo Luís Sousa a preferência pela representação humana, com mulheres ou homens em claras atitudes libertinas ou luxuriosas ${ }^{38}$.

Anos antes do mencionado por Luís Sousa ${ }^{39}$, Carlos Alberto Ferreira de Almeida apreciava que era comum encontrarem-se capitéis e modilhões que se poderiam considerar eróticos nas igrejas românicas ${ }^{40}$. De facto, temos vários exemplos, especialmente no norte de Portugal, onde esta arte mais se implantou. Sereias, harpias, homens e mulheres exibicionistas são exemplos que podemos encontrar em terras lusas. Para o demonstrar, apresentamos o Quadro 1, que elenca meia centena de imóveis e principais áreas simbólicas e temas escultóricos relacionados com a luxúria no românico português.

Quadro 1 - Lista de imóveis com a temática da luxúria em Portugal

\begin{tabular}{|c|c|c|c|}
\hline $\begin{array}{c}\text { Área } \\
\text { Simbólica }\end{array}$ & \multirow{2}{*}{ Tema } & Monumento/Imóvel & Localização/suporte \\
\hline \multirow{3}{*}{ Bestiário } & \multirow{3}{*}{ Sereia } & Igreja do Salvador de Ganfei (Valença) & Portal principal/Arquivolta \\
\cline { 3 - 4 } & & Sé de Braga (Braga) & Portal principal/Arquivolta \\
\cline { 3 - 4 } & & Igreja de São Romão de Arões (Fafe) & Abside/Modilhão \\
\cline { 3 - 4 } & & Igreja de São Pedro de Rates (Póvoa de Varzim) & Portal principal/Capitel \\
\hline
\end{tabular}

${ }^{34}$ Ibidem, p. 44.

35 ALMEIDA, Carlos Alberto Ferreira de - História da arte em Portugal: o românico. Lisboa: Publicações Alfa, 1986. p. 147.

${ }^{36}$ SOUSA, Luís Correia de - op. cit., p. 2.

${ }^{37}$ ALMEIDA, Carlos Alberto Ferreira de - História da arte em Portugal: o românico. Lisboa: Editorial Presença, 2001, p. 162.

${ }^{38}$ SOUSA, Luís Correia de - op. cit., p. 3.

${ }^{39}$ Ibidem.

${ }^{40}$ ALMEIDA, Carlos Alberto Ferreira de - História da arte em Portugal: o românico. Lisboa: Editorial Presença, 2001, p. 162.

Medievalista online № 17 I Janeiro - Junho 2015 (C) IEM - Instituto de Estudos Medievais 11 www2.fc sh.unl.pt/ie m/me die va lista 


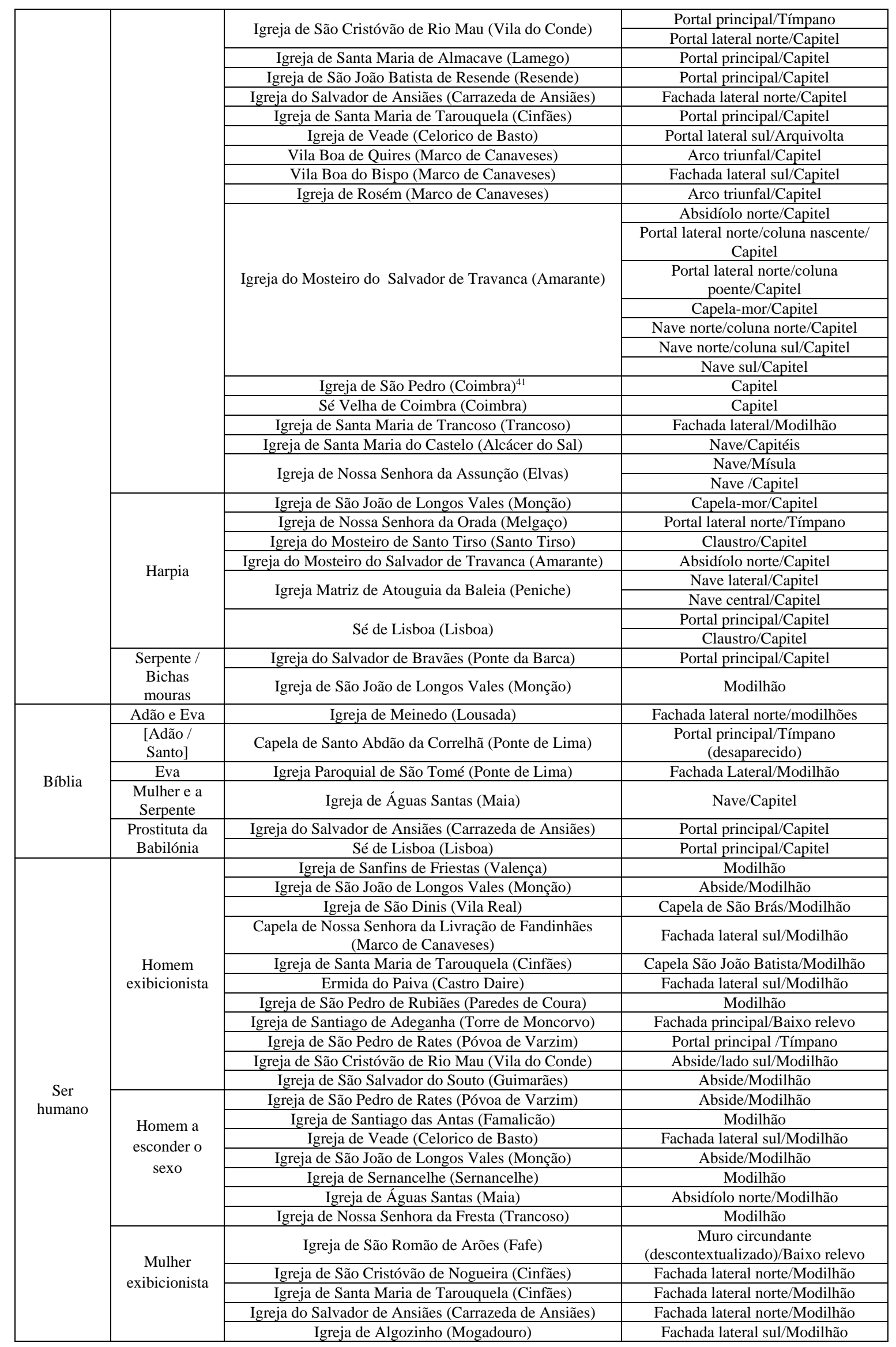

${ }^{41}$ Atualmente esta igreja não existe, por ter sido demolida para dar lugar à Cidade Universitária. 


\begin{tabular}{|c|c|c|c|}
\hline & & Igreja de Águas Santas (Maia) & Modilhão \\
\hline & & Igreja de Mangualde (Mangualde) & Modilhão \\
\hline & & Igreja do Salvador de Ganfei (Valença) & Portal principal/Capitel \\
\hline & & Igreja de Santa Maria (Barcelos) & Nave/Capitel \\
\hline & exibicionista - & Igreja de Santa Maria de Abade de Neiva (Barcelos) & Portal principal/capitel \\
\hline & & Igreja de São Pedro de Rates (Póvoa de Varzim) & Abside/Modilhão \\
\hline & & Igreja de São Pedro de Ferreira (Paços de Ferreira) & Capela-mor/Capitel \\
\hline & & Igreja de São Pedro de Rates (Póvoa de Varzim) & Abside/Modilhão \\
\hline & Casal & Igreja de São Pedro de Roriz (Santo Tirso) & Coro alto/Mísula \\
\hline & & Igreja São Cristóvão de Nogueira (Cinfães) & Fachada lateral norte/Modilhão \\
\hline & & Igreja de Santiago de Adeganha (Torre de Moncorvo) & Fachada lateral sul/ Baixo relevo \\
\hline & & Igreja de Santa Maria de Ermelo (Arcos de Valdevez) & Modilhão \\
\hline & & Igreja de São Pedro de Rubiães (Paredes de Coura) & Modilhão \\
\hline & Natividade / & Igreja de São João de Longos Vales (Monção) & Capela-mor/Abside/Modilhão \\
\hline & Parturientes & São Cláudio de Nogueira (Viana do Castelo) & Modilhão \\
\hline & & Joreia de Sernancelhe (Sernancelhe) & Abside/lado norte/Modilhão \\
\hline & & Igreja de Sernancelne (Sernanceline) & Abside/lado norte/Modilhão \\
\hline & & Igreja de Santiago de Adeganha (Torre de Moncorvo) & Fachada principal/Baixo relevo \\
\hline & & Igreja de Santa Maria de Ermelo (Aros de Valdevez) & Modilhão \\
\hline & Falo & Igreja de Algozinho (Mogadouro) & Modilhão \\
\hline & Falo & Igreja de Santo Isidoro (Marco de Canaveses) & Fachada lateral sul/Mísula \\
\hline & & Igreja do Salvador de Aveleda (Lousada) & Fachada lateral sul/Modilhão \\
\hline & & Igreja de Mangualde (Mangualde) & Modilhão \\
\hline $\begin{array}{l}\text { Mundo } \\
\text { animal }\end{array}$ & Animais & Igreja de Santa Maria (Barcelos) & Nave/Capitel \\
\hline
\end{tabular}

O quadro acima evidencia a ocorrência habitual da luxúria nos nossos imóveis românicos sob o chapéu de várias áreas simbólicas e temáticas, com especial destaque para o bestiário medieval e para o ser humano. Analisemos agora estes dados com maior pormenor, começando pelo bestiário medieval. A iconografia românica converteu criaturas imaginárias ou mitológicas em símbolos de virtudes e vícios, sendo possivelmente focalizadas, como já explanámos, para fins de instrução do indivíduo na $\mathrm{fé}^{42}$. Dois exemplos são as sereias e as harpias. Sendo uma temática que se repetirá até ao século $\mathrm{XVI}^{43}$, onde muitas vezes o erotismo não é evidente, o uso das sereias é extensível a várias civilizações. Se estas eram representadas na Grécia como sereiapássaro, chegadas à Idade Média cristã, estas representações são escassas ${ }^{44}$, sendo substituídas pela sereia-peixe, metade mulher na parte superior e metade de peixe, na parte inferior $^{45}$. Embora a sereia ilustre o sexo feminino, podemos conquanto encontrar

\footnotetext{
${ }^{42}$ MARQUES, Marisa Costa - op. cit., p. 4.

${ }^{43}$ VERMEERSCH, Paula Ferreira - "Considerações sobre representações fantásticas...”, p. 5.

${ }^{44}$ Esta situação verifica-se no românico português e com maior representação no centro do país, tendo Coimbra como foco difusor. Na arte coimbrã, surge associada a outros seres que partilham do seu caráter diabólico ou tentador como o dragão, o basílico, o centauro ou a harpia, sendo que esta última se confunde, certas vezes, com a sereia-pássaro. Na Sé Velha de Coimbra, podemos visualizar sereiaspássaro. No entanto, nesta região também observamos a sereia-peixe, de possível influência nortenha. Por exemplo, tínhamos esta representação na antiga igreja de São Pedro de Coimbra. Cf. MATTOSO, José (dir.) - XVII Exposição Europeia de Arte, Ciência e Cultura: Os Descobrimentos Portugueses e a Europa do Renascimento. Convento da Madre de Deus: Os Antecedentes Medievais dos Descobrimento. Lisboa: Imprensa Nacional-Casa da Moeda, 1983, pp. 272-273.
}

${ }^{45}$ RÉAU, Louis - Iconografia del arte cristiano: introducción general. Vol. 3. Barcelona: Ediciones del Serbal, 2008, p. 148. 
segundo Réau, mas de forma excecional, sereias com cabeça de homem ${ }^{46}$. Criaturas fabulosas, monstros semi-humanos ${ }^{47}$ ou híbridos, para o Cristianismo significavam a alma dividida entre o mundo terreno e o espiritual ou o mal, na sua ambiguidade e cinismo $^{48}$ através do pecado, da vaidade, da luxúria e da sedução ${ }^{49}$ :

"Las sirenas significan las mujeres locas que atraen a los hombres con sus cantos [...] Seductoras y temibles, atraen a los hombres con la caricia de sus cantos y los llevan a su perdición, a no ser que tomen la precaución, como el prudente Ulises, de taponarse las orejas" ${ }^{20}$.

Em Portugal, a sereia-peixe integra-se num bestiário popular e muito divulgado entre as bacias do Douro e do Cávado, sendo os dois principais focos dessa irradiação as igrejas de Travanca (Amarante) e Rates (Póvoa de Varzim) ${ }^{51}$. Elas podem apresentar-se com cauda simples ou dupla, sendo que o uso de cauda dupla tem duas interpretações, uma mais simbólica e outra mais arquitetónica: pretende simbolizar as pernas abertas, num sentido claro de oferta sexual ${ }^{52}$ ou estará relacionado com questões de simetria do capitel românico permitindo uma imagem completa de cada lado ${ }^{53}$.

\footnotetext{
${ }^{46}$ Ibidem, p. 147.

${ }^{47}$ Ibidem, p. 144.

${ }^{48}$ VERMEERSCH, Paula Ferreira - op. cit., p. 5.

${ }^{49}$ MARQUES, Marisa Costa - op. cit., pp. 9-10.

${ }^{50}$ RÉAU, Louis - op. cit., p. 147.

${ }^{51}$ MATTOSO, José (dir.) - op. cit., pp. 272-273.

${ }^{52}$ RODRIGUES, Jorge - op. cit., p. 304.

${ }^{53}$ A simetria do capitel românico também é visível nas sereias de uma só cauda mas que numa das mãos seguram um peixe. Ou seja, para manter a unidade do capitel, temos a cauda de um lado e o peixe do outro. in RÉAU, Louis - op. cit., p. 149.
} 


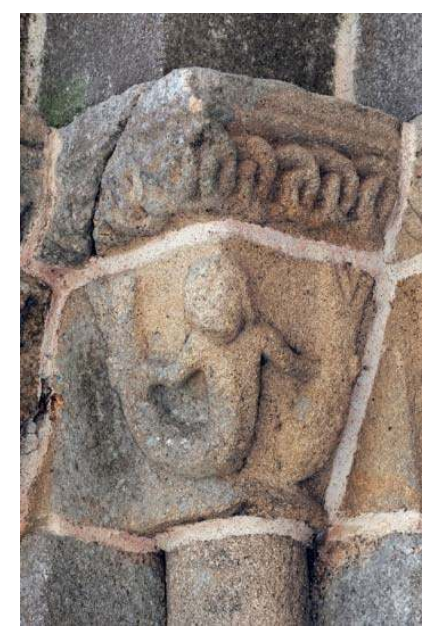

Fig. 1 - Sereia, Igreja do Mosteiro do Salvador de Travanca (Amarante). Fotografia do autor.

Como mencionado, a igreja do Mosteiro do Salvador de Travanca (Amarante) surge como um dos polos difusores de sereias-peixe no nosso território. De facto, temos várias representações deste animal mitológico e erótico nos capitéis do portal lateral norte, da capela-mor e das naves. Os dois capitéis com sereias representadas no portal lateral norte são de cauda única, segurando com a sua mão esquerda um peixe, procurando com a sua beleza, sedução e doce canto seduzir os herdeiros do céu para a perdição ${ }^{54}$. Por sua vez, as que se encontram no interior do espaço religioso, nos dois capitéis da nave norte, já se apresentam com dupla cauda. De indicar que estas duas representações no interior desta igreja possuem feições masculinas e com a curiosidade do umbigo saliente.

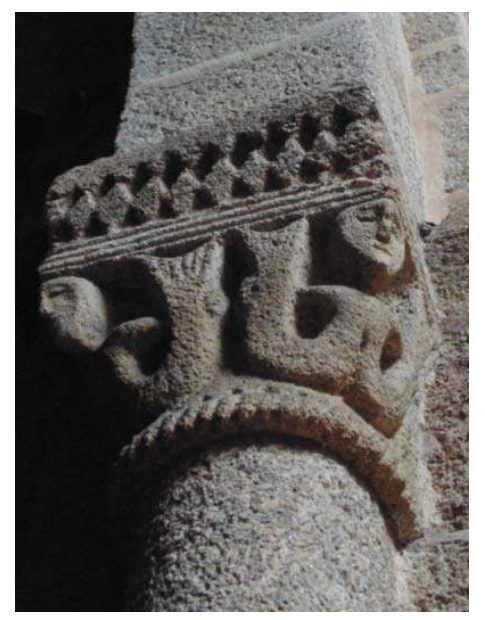

Fig. 2 - Sereias de feições masculinas e dupla cauda, Igreja do Mosteiro do Salvador de Travanca (Amarante). Fotografia do autor.

\footnotetext{
${ }^{54}$ LOIS GARCÍA, Xosé - Simbologia do românico de Amarante. Amarante: Edições do Tâmega, 1990, p. 36.
}

Medievalista online № 17। Janeiro - Junho 2015 (C) EM - Instituto de Estudos Me dievais 15 www2.fc sh.unl.pt/ie m/me die va lista 
Mas as representações deste animal mitológico não se ficam por aqui. Ainda no interior, na nave sul, num outro capitel, temos uma sereia cuja cauda está a ser mordida por um animal, possivelmente um leão ${ }^{55}$, num sinal de castigo por seduzir!

Embora Réau tenha escrito que sereias com feições de homens são menos representadas iconograficamente, o certo é que, para além das já citadas em Travanca, podemos encontrar outras similares na igreja do Salvador de Ansiães (Carrazeda de Ansiães), onde, na fachada norte, na janela sobre o portal, no capitel do lado direito, temos uma sereia, de feições masculinas e de dupla cauda ${ }^{56}$.

Voltando à temática das sereias femininas, em Rio Mau (Vila do Conde) no tímpano axial, lado direito, desfrutamos de uma sereia de dupla cauda que sustenta a lua ${ }^{57}$ e uma outra que, ao lado de um Tritão, em capitel no portal norte, se aproxima de uma atitude de oferta sexual ao seu $\operatorname{par}^{58}$.

Já em Rosém (Marco de Canaveses), temos um capitel com a representação de sereias, apresentando-se estas com olhos, nariz, boca, rosto, cabelo de tranças seriadas e entrelaçadas no princípio da cauda, que é segurada pela mão da sereia oposta ${ }^{59}$.

Sobre a utilização nas igrejas deste tipo de representação, convém anotar a curiosidade, mencionada por Réau, de que, na Idade Média, o uso dos animais era algo natural, do quotidiano, sendo mais um capítulo da moral do que da história natural. Os animais eram assim esboços do próprio homem, espelhos da sua vida e serviam para caricaturar as virtudes, as paixões ou os seus vícios. O bestiário cristão era visto como a "Bible moralisée", em que mais que uma enciclopédia zoológica era principalmente um complemento moral dos fiéis ${ }^{60}$. Dentro deste pensamento também disserta Catarina Barreira, quando expressa que o homem medieval não fazia distinção entre os animais

\footnotetext{
55 De advertir que este animal na simbologia cristã podia significar tanto o benigno como o maligno, podendo representar Cristo ou Satanás consoante o contexto. in RÉAU, Louis - op. cit., p. 133. Neste caso em estudo, o leão está associado ao bem, encontrando-se a morder o mal (a sereia sedutora).
}

56 LOPES, Roger Teixeira - Carrazeda de Ansiães: património artístico. Mirandela: João Azevedo Editor, 1996. p. 76.

57 ALMEIDA, Carlos Aberto Ferreira de - "Primeiras impressões sobre a arquitectura românica portuguesa". in Revista da Faculdade de Letras: História. Porto: Universidade do Porto / Faculdade de Letras. Série I, vol. 2 (1971) p. 111.

${ }^{58}$ RODRIGUES, Jorge - “A escultura românica", p. 304.

59 SILVA, João Ribeiro da - "Elementos românicos da Igreja de Rosém". in MARCO HISTÓRICO E CULTURAL - Atas de eventos marcoenses: 1988-1998. Marco de Canaveses: Câmara Municipal do Marco de Canaveses, 1998, p. 152.

${ }^{60}$ RÉAU, Louis - op. cit., p. 147.

Medievalista online № 17। Janeiro - Junho $2015 \odot \mathbb{E M}$ - Instituto de Estudos Medieva is 16 www2.fc sh.unl.pt/ ie $\mathrm{m} / \mathrm{me}$ die va lista 
reais que faziam parte do seu quotidiano - como o cão - e os animais fantásticos ou híbridos, como a sereia. Para os medievais eram todos "verdadeiros" e reais 61 .

Para João Ribeiro da Silva ${ }^{62}$ e Marisa Costa Marques ${ }^{63}$, o tema da sereia é dos mais comuns no nosso românico. O levantamento efetuado para este artigo parece atestar o referido pelos autores. De facto, foi a temática que mais surgiu representada iconograficamente nos imóveis românicos. Por sua vez, as harpias - outro animal também mitológico, híbrido e monstruoso - com corpo de abutre e asas, mas com rosto feminino e seios - pretendiam ilustrar os vícios do homem, as suas paixões obsessivas e o remorso inerente à satisfação das mesmas ${ }^{64}$.

Segundo interpretação de Xosé Lois García ${ }^{65}$, temos esta figura lendária na abside norte do Mosteiro do Salvador de Travanca (Amarante), onde duas harpias ilustram os vícios mundanos e as paixões viciosas a que os homens estavam sujeitos. Na igreja de Nossa Senhora da Orada (Melgaço), desfrutamos também de uma harpia no tímpano do portal, a ladear a árvore da vida ${ }^{66}$. Para além destes dois exemplos, podemos encontrar outros testemunhos na igreja do Mosteiro de Santo Tirso e na matriz de Atouguia da Baleia (Peniche $)^{67}$. Sereias e harpias constituem assim interessantes formas de levar os homens de fé a perderem-se no pecado.

Dentro do bestiário medieval, de citar as serpentes dotadas de cabeças humanas ou de mulheres com cabeleiras, como se expõe no portal principal de Bravães (Ponte da Barca). Para Carlos Alberto Ferreira de Almeida, estas representam as chamadas "bichas mouras"68. Segundo a lenda, uma moura infeliz ter-se-ia transformado em bicha por causa de uma falta grave, cumprindo assim uma vida penosa. Ela aparecia em noites

${ }^{61}$ BARREIRA, Catarina Alexandra Martins Fernandes - Gárgulas: representações do feio e do grotesco no contexto português: séculos XIII a XVI. [Em Linha] Lisboa: Tese de doutoramento em Belas Artes, Universidade de Lisboa - Faculdade de Belas Artes, 2010. Vol. I, p. 756. [Consultada a 08.11.2013]. Disponível em: http://repositorio.ul.pt/handle/10451/2590.

${ }^{62}$ SILVA, João Ribeiro da - "Elementos românicos da Igreja de Rosém". in MARCO HISTÓRICO E CULTURAL - Atas de eventos marcoenses: 1988-1998. Marco de Canaveses: Câmara Municipal do Marco de Canaveses, 1998, p. 152.

${ }^{63}$ MARQUES, Marisa Costa - op. cit., p. 8.

${ }^{64}$ Ibidem, p. 8.

${ }^{65}$ LOIS GARCÍA, Xosé - Simbologia do românico de Amarante. Amarante: Edições do Tâmega, 1990, p. 37.

${ }^{66}$ ALMEIDA, Carlos Alberto Ferreira de - História da arte em Portugal: o românico. Lisboa: Publicações Alfa, 1986, p. 149.

${ }^{67}$ MARQUES, Marisa Costa - op. cit., p. 8.

${ }^{68}$ ALMEIDA, Carlos Alberto Ferreira de - História da arte em Portugal: o românico. Lisboa: Editorial Presença, 2001, p. 160.

Medievalista online № 17 । Jane iro - Junho $2015 \odot \mathbb{E}$ - Instituto de Estudo s Medievais 17 www2.fc sh.unl.pt/ie m/me die va lista 
de luar e às vezes até de dia, deixando na sua caminhada um rasto brilhante. Ninguém ousava aproximar-se dela, pois correria o risco de se transformar em bicha ${ }^{69}$. Para Maria Leonor Botelho, quer a temática quer a modelação deste capitel em Bravães, mostram a influência galega - mais concretamente da diocese de Tui - no românico português ${ }^{70}$. No que concerne à simbologia bíblica, o pecado começou com a criação da própria humanidade aquando da tentação de Adão e Eva. Estes foram criados à imagem e semelhança de Deus. Viviam nus, sem vergonha. Mas ao comerem do fruto proibido, pecaram e "então abriram-se os olhos aos dois, e eles perceberam que estavam nus" (Gn $3,7)^{71}$. Os três modilhões no alçado norte da igreja de Meinedo, Lousada, interpretados sequencialmente, quererão transmitir essa mensagem.

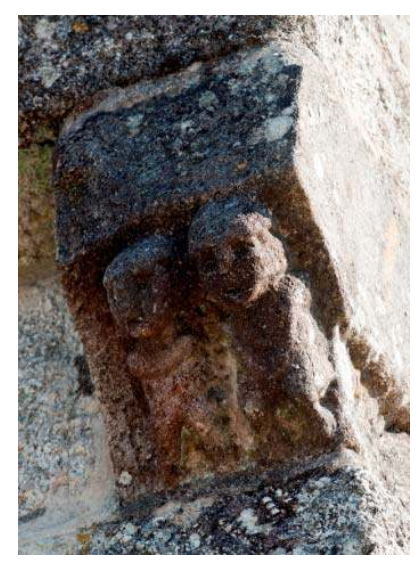

Fig. 3 - Adão e Eva, Igreja de Santa Maria de Meinedo (Lousada). Foto: Arquivo da Rota do Românico.

Ainda relacionado com o pecado original, devemos referir-nos ao capitel da "mulher e a serpente", como Aarão de Lacerda ${ }^{72}$ o designou na Igreja de Águas Santas (Maia). Dois bustos femininos surgem de braços erguidos, sendo circundados pelo que parecem ser serpentes. Sousa Oliveira considera que simbolizam a tentativa da alma virtuosa em se libertar do pecado ${ }^{73}$.

\footnotetext{
${ }^{69}$ VALLE, Carlos - Revista de Etnografia, Tradições Populares de Vila Nova de Gaia. Porto: Junta Distrital do Porto, 1965, pp. 129-130.

${ }^{70}$ BOTELHO, Maria Leonor - "Mosteiro de São Salvador de Bravães". in NUÑO GONZÁLEZ, Jaime (coord.) - Arte românica em Portugal. Madrid: Fundación Santa María La Real, 2010, p. 191.

${ }^{71}$ A BÍBLIA Sagrada. Lisboa: Paulus Editora, 2009.

${ }^{72}$ OLIVEIRA, A. de Sousa - "Temas psicomáquicos na escultura românica decorativa". Lucerna. Vol. V (1966), p. 662.

${ }^{73}$ Ibidem.
}

Medievalista online № 17। Jane iro - Junho $2015 \odot \mathbb{E M}$ - Instituto de Estudos Medievais 18 www2.fc sh.unl.pt/ ie m/me d ie va lista 


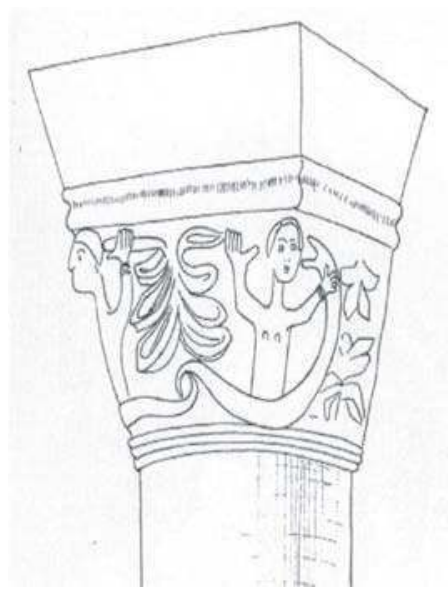

Fig. 4 - Desenho da Mulher e a Serpente, Igreja de Águas Santas (Maia). Imagem reproduzida a partir de OLIVEIRA, A. de Sousa - "Temas psicomáquicos na escultura românica decorativa". Lucerna. Vol. V (1966), p. 666.

Peça fundamental e figura central no tímpano do portal ocidental da capela de Santo Abdão $^{74}$ (Ponte de Lima) era a representação deste santo padroeiro com "hum páo lizo que lhe encobre a parte mais impura"75 e que a 8 de agosto de 1750, o visitador Francisco Diogo de Azevedo, abade de São Pedro de Esgueiros, por considerar a imagem obscena, ordenou ao Pároco que, por conta das esmolas, mandasse picar toda a estátua deixando a pedra lisa, sob pena de ser suspenso se não o fizesse num prazo de 20 dias $^{76}$. Pelo que já não é possível visualizar esta imagem no tímpano ${ }^{77}$. No entanto, várias têm sido as interpretações acerca do que simbolizaria. Uma delas considera que esta escultura representaria Adão, explicando-se pelo facto de haver uma ave a ladear a escultura central, como que indicando aos crentes o Paraíso ${ }^{78}$.

Ainda no âmbito do simbolismo bíblico, na vertente escatológica, podemos referir a possível representação da prostituta ou meretriz da Babilónia num dos capitéis do portal

\footnotetext{
${ }^{74}$ Abdão é uma das derivações de Adão. Cf. NOÉ, Paula - "Capela de Santo Abdão". in Monumentos.pt [Em linha]. Sacavém: IHRU, 1992. [Consultado a 08.11.2013]. Disponível em: http://www.monumentos.pt/Site/APP_PagesUser/SIPA.aspx?id=2106.

${ }^{75}$ ALVES, Lourenço - "Igrejas e Capelas românicas da Ribeira Lima". in Caminiana. N ${ }^{\circ}$ 7, ano IV (1982) p. 81.

${ }^{76}$ NOÉ, Paula - op. cit..

${ }^{77}$ De referir contudo que ao censor escapou a imagem de Eva nua, que se encontra num modilhão por debaixo do beiral da igreja de São Tomé. Segundo Jorge Rodrigues, talvez naquele espaço o choque das mentalidades fosse menor. Cf. RODRIGUES, Jorge - "O mundo românico...", p. 55.
}

${ }^{78}$ NOÉ, Paula - op. cit..

Medievalista online № 17 । Ja neiro - Junho 2015 ( $\mathbb{E M}$ - Instituto de Estudos Medieva is 19 www2.fc sh.unl.pt/ie m/me die va lista 
principal da Sé de Lisboa. Esta mulher encontra-se coroada, de pé, em atitude lasciva e empunhando o que parece ser um cálice, enquadrada por plantas exóticas e outras desconhecidas $^{79}$. Embora tenha de ser interpretada num contexto mais vasto, nomeadamente na associação com os restantes capitéis ${ }^{80}$, a sua atitude sensual, juntamente com o cálice - com intuito de embriagar com o vinho os reis da terra que a adoram -, pode ser sinónimo dos prazeres carnais ${ }^{81}$. Num contexto doutrinário, quererá representar uma advertência aos cristãos para que não caiam na infidelidade a Deus.

As representações com significado erótico ou sexual no nosso românico não se ficam pelas criaturas fabulosas e pelos temas bíblicos. O simbolismo terreno também foi praticado, e de forma abundante ${ }^{82}$, sendo que nestes o sexo exposto é mais nítido se comparado com as temáticas até agora estudadas.

Para uma parte dos pensadores e religiosos medievais, a grande responsável pelo pecado carnal foi a mulher. Ela representava a luxúria, a sensualidade, a grande incitadora para que o homem tivesse condutas pecaminosas ${ }^{83}$. No período histórico em questão, o pecado da luxúria era um pecado feminino e dos piores que se poderia $\operatorname{cometer}^{84}$.

Em várias igrejas temos representações da mulher pecadora. Por exemplo, em Roriz (Santo Tirso), numa mísula que sustenta o coro-alto, uma mulher exibe os seios através do vestido arregaçado, dando a sensação de estar a seduzir um homem que, no lado oposto e numa outra mísula, arregala os olhos observando cena tão provocadora ${ }^{85}$. Pela expressão do homem, a atitude da mulher terá surtido efeito!

$\mathrm{Na}$ igreja de Algozinho (Mogadouro), temos uma mulher com seios desnudados e pernas apartadas, onde o convite ao pecado é evidente. Por sua vez, nas igrejas de

\footnotetext{
${ }^{79}$ FERNANDES, Paulo Almeida - "Iconografia do apocalipse: uma nova leitura do portal ocidental da Sé de Lisboa". in Estudos Património. Lisboa: IPPAR. Nº 7 (2004), p. 93.

${ }^{80}$ Relacionados com o Livro do Apocalipse, estando divididos em dois grupos temáticos, característicos da universalidade simbólica românica: o triunfo do Bem, nos capitéis próximos do centro com o "Cavaleiro vitorioso" (Ap. 6:1-2) e "S. Miguel triunfante sobre o dragão" (Ap. 12:7-8); e manifestações do Mal nos capitéis das extremidades com a cena das "duas testemunhas de Sodoma e Egito" (Ap. 11:8) e a "Prostituta de Babilónia" (Ap. 17:1-5). Ver FERNANDES, Paulo Almeida - op. cit., p. 95.

${ }^{81}$ RÉAU, Louis - Iconografia del arte cristiano: iconografia de la Biblia: Nuevo Testamento. Barcelona: Ediciones del Serbal, 2008, p. 739.

82 CAMILLE, Michael - Images dans les marges: aux limites de l'art médiéval. Paris: Gallimard, 1997, pp. 102-103.

${ }^{83}$ SERNA, Andrés - op. cit., p. 6.

${ }^{84}$ SERRANO, Ferran Salgado - "La colegiata de San pedro de Cervatos". Revista Arqueología, historia y viajes sobre el mundo medieval. ISSN 1698-0387. No 44 (2012), p. 61.

85 BOTELHO, Maria Leonor - "Mosteiro de Roriz". in NUÑO GONZÁLEZ, Jaime (coord.) - Arte românica em Portugal. Madrid: Fundación Santa María La Real, 2010, p. 252.
} 
Mangualde e de Ansiães, existe respetivamente uma mulher a mostrar os seios ${ }^{86}$ e uma outra com grande barriga, a agarrar a cabeça e a exibir também os seios ${ }^{87}$. Por fim, em modilhão no alçado norte da igreja de Tarouquela (Cinfães), embora esteja corroído pelo tempo, assistimos a mais uma representação, sendo que desta vez a mulher expõe o órgão genital.

Mais contidas mas mesmo assim representando a luxúria, temos as bailarinas ou dançarinas nas igrejas de Santa Maria de Abade de Neiva (Barcelos) e em São Pedro de Rates (Póvoa de Varzim), com as mãos nas ancas ${ }^{88}$, como que convidando para a tentação. Por sua vez, em Ganfei (Valença) e Santa Maria de Barcelos, as bailarinas figuradas entregam-se à lassidão moral e ao prazer da dança ${ }^{89}$. O mesmo quererá representar o capitel da capela-mor da igreja de São Pedro de Ferreira, em Paços de Ferreira, onde uma dançarina acrobática é acompanhada de um músico tocando pandeiro $^{90}$.

No entanto, não existem só mulheres exibicionistas. Também encontrámos o sexo oposto. Por exemplo, segundo Ferreira de Almeida, no portal axial de São Pedro de Rates (Póvoa de Varzim), Cristo é assistido por duas figuras nimbadas sob cujos pés, deitado por terra, se encontra um homem $\mathrm{nu}^{91}$. Igual situação é comprovável em Rubiães (Paredes de Coura), onde existe um modilhão com homem expondo o pénis ${ }^{92}$. Outros exemplos podem ser encontrados em dois modilhões na igreja de Sanfins de Friestas (Valença), em que num deles um homem aproveita uma pirueta de acrobata para mostrar o sexo, enquanto que, no modilhão ao lado, outro homem, sentado e nu, acha-se a amanhar o sexo. Já no modilhão que podemos visualizar em Salvador do

\footnotetext{
${ }^{86}$ RODRIGUES, Jorge - “A escultura románica”, p. 303.

${ }^{87}$ LOPES, Roger Teixeira - Carrazeda de Ansiães: património artístico. Mirandela: João Azevedo Editor, 1996, p. 79.

${ }^{88}$ RODRIGUES, Jorge - Galilea, Locus e Memória: panteões, estruturas funerárias e espaços religiosos associados em Portugal..., Lisboa: Tese de doutoramento em História da Arte apresentada à Universidade Nova de Lisboa, 2011. Vol. I, p. 342.

${ }^{89}$ RODRIGUES, Jorge - “A escultura românica”, pp.282-283.

90 ALMEIDA, Carlos Alberto Ferreira de - História da arte em Portugal: o românico. Lisboa: Editorial Presença, 2001, p. 160.

91 ALMEIDA, Carlos Alberto Ferreira de - "Primeiras impressões sobre a arquitectura românica...”, p. 111.

92 ALMEIDA, Carlos Alberto Ferreira de - História da arte em Portugal: o românico. Lisboa: Publicações Alfa, 1986, p. 149.
} 
Souto (Guimarães), o homem apresenta-se a exibir o seu órgão sexual, estando este ereto $^{93}$.

Num desenho mais próximo da temática de Adão e do pecado original ${ }^{94}$, podemos visualizar homens que, tapando o órgão genital, demonstram uma atitude consciente de vergonha ou inquietação face ao exposto publicamente. Por exemplo, as igrejas de Águas Santas (Maia) e de Veade (Celorico de Basto) mostram-nos homens a taparem com as duas mãos o símbolo da masculinidade.

Na Capela de Nossa Senhora da Livração de Fandinhães (Marco de Canaveses), no alçado lateral sul, temos num modilhão um homem que se apresenta nu, com a mão direita nos órgãos genitais e a mão esquerda a tapar o rosto, como se estivesse envergonhado. Outro modilhão semelhante, desta feita no interior da Capela de São João Baptista, anexa ao lado sul da Igreja de Tarouquela (Cinfães), apresenta mais um exibicionista, nu e vicioso ${ }^{95}$, que com a mão esquerda segura o órgão sexual, enquanto com a outra afaga o queixo, em jeito de inquietação. Por fim, na Igreja de Adeganha (Torre de Moncorvo), temos, em baixo-relevo, um homem que, segurando nas duas mãos objetos, mostra o seu órgão sexual. Mas qual o motivo para taparem o órgão sexual? Provavelmente cometeram o pecado carnal, estando envergonhados pela sua nude $z^{96}$.

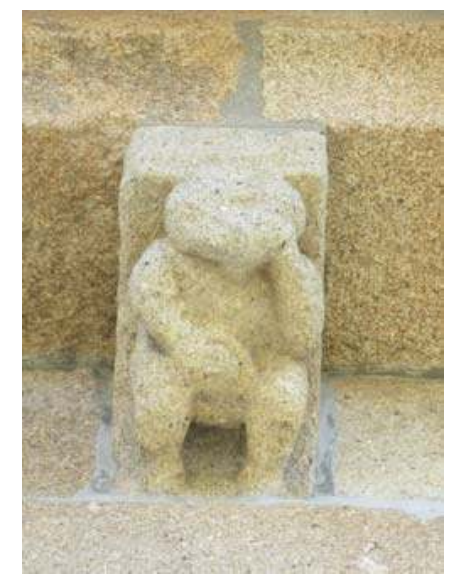

Fig. 5 - Homem escondendo órgão sexual ao mesmo tempo que tapa o rosto, Capela de Nossa Senhora da Livração de Fandinhães (Marco de Canaveses). Fotografia do autor.

\footnotetext{
${ }^{93}$ RODRIGUES, Jorge - "A escultura românica”, p. 303.

${ }^{94}$ Ibidem, p. 304.

${ }^{95}$ Ibidem, p. 369.

${ }^{96}$ Ibidem, p. 304 e LIMA, Alexandra Cerveira Pinto S. (coord.) - Terras do Côa: da Malcata ao Reboredo [Em linha]. Guarda: Estrela-Côa, 1998, p. 114. [Consultado a 09.10.2013]. Disponível em: http://www.arte-coa.pt/Ficheiros/Bibliografia/1686/1686.pt.pdf.
} 


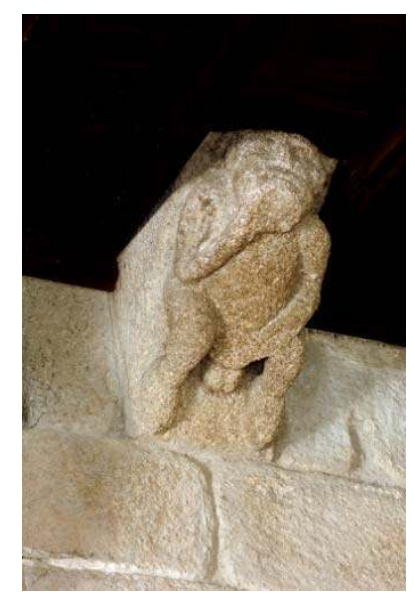

Fig. 6 - Homem a segurar o órgão sexual, Igreja de Tarouquela (Cinfães). Fotografia: Arquivo Rota do Românico.

A par destas figurações existem outras com a representação individual do órgão sexual masculino, costume porventura herdado do mundo antigo ${ }^{97}$. Exemplos expõem-se em Ermelo (Arcos de Valdevez) - embora aqui o símbolo fálico se apresente pouco explícito devido a estar eufemizado por entre a decoração vegetalista ${ }^{98}$ - e nas igrejas de Algozinho (Mogadouro), de Santo Isidoro (Marco de Canaveses), do Salvador de Aveleda (Lousada) e de Mangualde. Estes casos poderão ter, através do erotismo, uma função profilática ${ }^{99}$ para promover a fertilidade entre os cristãos.

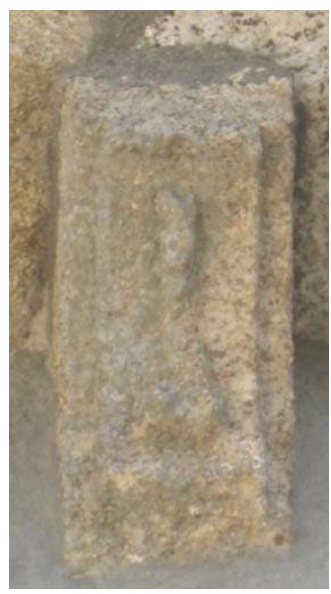

Fig. 7 - Falo na Igreja do Salvador de Aveleda (Lousada). Fotografia do autor.

\footnotetext{
${ }^{97}$ SERNA, Andrés - op. cit., p. 6.

${ }^{98}$ RODRIGUES, Jorge - op. cit., p. 303.

${ }^{99}$ SERNA, Andrés - op. cit., p. 6.
} 
Para terminar a temática dos homens exibicionistas, devemos aludir à identificação proposta por Manuel Real, que considera que na cornija do lado sul da abside da igreja de São Pedro de Rates (Póvoa de Varzim), o homem esculpido numa postura sentado de pernas cruzadas representa uma imagem masculina de luxúria. Para o autor, este modelo é de inspiração galega, sendo um reflexo da figura de Priape de pernas cruzadas, que se pode ver na igreja de San Pedro de Ansemil, no concelho de Silleda, Galiza $(\text { Espanha })^{100}$.

Como referido anteriormente, a religião católica na Idade Média impôs o sexo dentro do casamento. A Bíblia é explícita neste aspeto quando recomenda que "todos respeitem o matrimónio e não desonrem o leito nupcial, pois Deus julgará os libertinos e adúlteros" (Hb 13,4). O modilhão que se encontra em São Cristóvão de Nogueira (Cinfães) representa um casal abraçado, porventura num ato amoroso, no entanto, pouco claro sexualmente ${ }^{101}$. Cena mais nítida a nível sexual encontra-se em Santiago de Adeganha (Torre de Moncorvo) onde, num baixo-relevo, temos um casal, sendo que a mulher encontra-se deitada, com a sua cabeça sobre o pé esquerdo fletido do homem. Este, por sua vez, expõe o sexo, enquanto na mão direita segura um objeto, tendo a outra mão junto da cabeça da mulher.

Uma questão que se coloca sobre este tipo de figuração é a de saber até que ponto podemos considerar certas representações eróticas. Exemplos concretos são as representações da Natividade ou de parturientes.

Em Santiago de Adeganha (Torre de Moncorvo), na fachada principal, por acima do portal, temos um baixo-relevo representando três mulheres em pé, unidas pelos braços, com as cabeças cobertas e calçado bicudo. A figura central está a dar à luz e é protegida pelas outras duas ${ }^{102}$. Esta cena poderá querer representar o nascimento de Jesus Cristo, com a Virgem ao centro, sendo ladeada por duas parturientes a ajudarem a Mãe do Salvador, tendo estas sido trazidas por José ${ }^{103}$.

\footnotetext{
${ }^{100}$ REAL, Manuel Luís - "La sculpture figurative dans l'art roman du Portugal". in GRAF, Gerhard Portugal Roman. Yonne: Zodiaque, 1986, p. 42.

${ }^{101}$ Convém salientar que esta cena é bastante semelhante a uma outra existente na igreja de Nuestra Señora de la Asunción, em Castillejo de Robledo, província de Soria, comunidade de Castela e Leão, Espanha.

102 ROSAS, Lúcia - "Igreja de São Tiago de Adeganha". in NUÑO GONZÁLEZ, Jaime - Arte românica em Portugal. Madrid: Fundación Santa María La Real, 2010, p. 286.

103 RÉAU, Louis - Iconografia del arte cristiano: iconografia de la Biblia: Nuevo Testamento. Barcelona: Ediciones del Serbal, 2008, p. 230.
} 


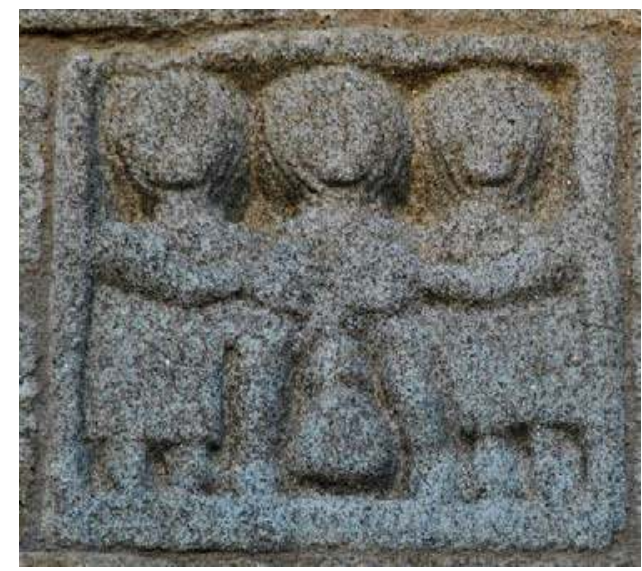

Fig. 8 - Parturientes, Igreja de Santiago de Adeganha (Torre de Moncorvo). Fotografia do autor.

Outros exemplos se encontram na igreja de Sernancelhe, onde temos dois modilhões sobre o tema em análise. Num deles, a parturiente está com as mãos a amparar a barriga, com peito entumecido e sexo desnudo ${ }^{104}$. Neste caso, o sexo está perfeitamente visível. Se neste a mulher está em trabalho de parto, no outro modilhão temos já a criança a nascer com tudo em exposição ${ }^{105}$. Uma das possíveis interpretações para estas duas cenas poderá ser a chamada de atenção dos fiéis para a fecundidade. Contudo, se usarmos a mesma interpretação de Ferreira de Almeida que, para as mulheres a darem à luz em Rubiães (Paredes de Coura) e Longos Vales (Monção), as considerou como cenas eróticas ${ }^{106}$, os exemplos acima expostos podem ser entendidos no mesmo sentido. Quanto à quarta área simbólica inscrita no Quadro 1, esta reporta-se a práticas lascivas, mas desta vez entre animais. Para Michael Camille, a arte românica utilizou os animais para fazer a fronteira entre o puro e o impuro ${ }^{107}$. Na igreja de Santa Maria de Barcelos, deparamo-nos com um capitel na nave com dois animais, em que um deles lambe o traseiro do outro ${ }^{108}$.

Outros elementos indispensáveis para melhor entendimento da temática da luxúria são os locais e os suportes utilizados, para que possamos saber com maior exatidão se esta temática era aplicada perto ou longe dos espaços mais sagrados de uma igreja. Tendo

${ }^{104}$ AZEVEDO, Cândido de - Igreja românica de Sernancelhe. Sernancelhe: Câmara Municipal de Sernancelhe, 2012, p. 75.

${ }^{105}$ Ibidem, p. 75.

${ }^{106}$ ALMEIDA, Carlos Alberto Ferreira de - História da arte em Portugal: o românico. Lisboa: Editorial Presença, 2001, p. 162.

${ }^{107}$ CAMILLE, Michael - Images dans les marges..., p. 99.

${ }^{108}$ RODRIGUES, Jorge - “A escultura românica”, p. 283.

Medievalista online № 17 । Jane iro - Junho $2015 \odot \mathbb{E}$ - Instituto de Estudos Medievais 25 www2.fc sh.unl.pt/ie m/me die va lista 
por base os imóveis descritos no Quadro 1, apresentamos agora os quadros 2 e 3, onde expomos os locais e os suportes usados para transmitir a luxúria.

Quadro 2 - Locais com representações luxuriosas

\begin{tabular}{|c|c|c|}
\hline \multicolumn{1}{|c|}{ Locais } & Quantidade \\
\hline \multirow{4}{*}{ Exterior } & Abside & 10 \\
\cline { 2 - 3 } & Absidíolo & 1 \\
\cline { 2 - 3 } & Capela anexa & 2 \\
\cline { 2 - 3 } & Fachada lateral & 15 \\
\cline { 2 - 3 } & Fachada principal & 2 \\
\cline { 2 - 3 } & Portal lateral & 6 \\
\cline { 2 - 3 } & Portal principal & 15 \\
\hline \multirow{4}{*}{ Interior } & Subtotal & $\mathbf{5 1}$ \\
\cline { 2 - 3 } & Absidíolos & 2 \\
\cline { 2 - 3 } & Arco triunfal & 4 \\
\cline { 2 - 3 } & Capela-mor & 11 \\
\cline { 2 - 3 } & Coro-alto & 2 \\
\cline { 2 - 3 } & Nave & $\mathbf{2 2}$ \\
\cline { 2 - 3 } & Outros locais: Claustro & 17 \\
\hline Sem referência/Descontextualizado & $\mathbf{9 0}$ \\
\hline & Total & 1 \\
\hline
\end{tabular}

Um dado a realçar do Quadro 2 é o facto da maioria das representações se situarem no exterior dos edifícios religiosos. Esta situação vem de encontro ao que Michael Camille escreveu há duas décadas atrás quando afirmou ser sobretudo no exterior dos edifícios religiosos que encontramos este tipo de imagens ${ }^{109}$. Neste espaço, o destaque é dado aos portais principais. Como estes portais são considerados "as portas do Céu", ou seja, a entrada para o Reino de Deus, não será de estranhar a sua representação tendo em atenção os fins simbólicos a que se destinava o uso de imagens luxuriosas. Ainda no exterior, são igualmente de mencionar as fachadas laterais que, em simultâneo com os portais, constituem um outro local privilegiado para este tipo de escultura.

No interior das igrejas, o principal local utilizado é a nave, embora existam em todos os espaços interiores de uma igreja, desde a capela-mor, arco triunfal até ao coro-alto, conquanto em menor quantidade.

${ }^{109}$ CAMILLE, Michael - op. cit., p. 99.

Medievalista online № 17 I Janeiro - Junho 2015 (C) IEM - Instituto de Estudos Medieva is 26 www2.fc sh.unl.pt/ ie m/me die va lista 


\section{Quadro 3 - Suportes com representações luxuriosas}

\begin{tabular}{|c|c|}
\hline Suporte & Quantidade \\
\hline Arquivolta & 3 \\
\hline Baixo-relevo & 4 \\
\hline Capitel & 36 \\
\hline Mísula & 3 \\
\hline Modilhão & 40 \\
\hline Tímpano & 4 \\
\hline Total & $\mathbf{9 0}$ \\
\hline
\end{tabular}

Quanto aos suportes, os modilhões apresentam-se como o suporte preferencial, apesar dos capitéis serem também bastante aproveitados. Esta informação vem, de certa forma, confirmar o expresso no Quadro 2, pois um dos locais preferenciais no exterior das igrejas para a representação da luxúria são as fachadas laterais, locais por excelência para o uso de modilhões. Por conseguinte, estes dados parecem contrariar tenuemente o defendido por Jorge Rodrigues ${ }^{110}$ e León Gomez ${ }^{111}$, quando consideram que este tipo de escultura é mais usual na periferia das igrejas, onde os artistas tinham maior liberdade. De facto, na periferia encontrámos uma boa parte das representações, mas não é o único local, podendo ser encontradas em diversos outros espaços, com destaque para os portais principais, mas também nas naves, arcos triunfais ou mesmo nas capelas-mor.

Como nota final desta interpretação, devemos lembrar que muitos outros exemplares poderiam existir. Todavia, a partir do século XVI, estas representações foram depuradas das igrejas a mando do Concílio de Trento ${ }^{112}$, tendo por base uma nova filosofa sobre a castidade, a vigilância do pecado ${ }^{113}$ e o uso de imagens nos espaços religiosos:

"[...] estabelece o Santo Concílio que a ninguém seja lícito pôr ou permitir que se ponha qualquer imagem nua e nova em lugar algum, nem mesmo igreja que seja de qualquer modo isenta de modo a não possuir aprovação do Bispo"114.

\footnotetext{
${ }^{110}$ RODRIGUES, Jorge - op. cit., p. 296.

${ }^{111}$ LEÓN GÓMEZ - "Rutas por el románico...", p. 4.

${ }^{112}$ RÉAU, Louis - op. cit., p. 233.

${ }^{113}$ SERNA, Andrés - op. cit., p. 7.

${ }^{114}$ Citado por MARTINS, Fausto Sanches - "As imagens das nossas igrejas". in CONGRESSO SOBRE A DIOCESE DO PORTO, I, 2002 - Tempos e lugares de memória: actas. Porto/Arouca: UC/FLUP, 2002. Vol. I, p. 216.
}

Medievalista online № 17 । Jane iro - Junho $2015 \odot \mathbb{E}$ - Instituto de Estudos Medievais 27 www2.fc sh.unl.p $\mathrm{t} / \mathrm{ie} \mathrm{m} / \mathrm{me}$ die va lista 
Exemplo deste decreto é o que se verificou na já referida capela de Santo Abdão, em Ponte de Lima.

\section{Conclusão}

A iconografia da luxúria no românico português é extensível a todo o território, embora se note maior incidência a norte do rio Mondego que, de certa forma, corresponde à zona onde o estilo artístico em estudo mais se implantou. Do Minho ao Alentejo, possuímos exemplos de figuras mitológicas, passagens bíblicas ou representações do quotidiano onde a mensagem da luta contra este pecado é evidente.

Todavia, devemos reconhecer que a maioria das figurações objeto do presente levantamento foram encontradas na região minhota, levando-nos a concordar com Manuel Luís Real quando refere que nesta região portuguesa existe uma tendência para representar homens e mulheres em atitude libertinas ${ }^{115}$.

Em Portugal, a luxúria encontra-se especialmente centrada na temática das sereias, com cerca de um terço (30\%) dos 90 exemplos apresentados, embora esta criatura possa ter outros significados. Se seguirmos a via luxuriosa, importa recordar o Mosteiro de Travanca pela diversidade que apresenta sobre as sereias-peixe, com feições femininas, masculinas, de cauda simples ou dupla e aprisionadas a outros seres. Ao todo temos neste imóvel sete representações. É, de facto, um dos locais difusores e de maior variedade temática sobre as sereias em Portugal. Por exemplo, a sereia da Igreja de Santa Maria de Almocave (Lamego) apresenta um repositório escultórico semelhante a Travanca ${ }^{116}$.

Notamos também outras influências regionais, com especial atenção para as regiões do Minho, Cávado e Douro no âmbito da representação da sereia-peixe. Contudo, esta influência também se nota a nível internacional, especialmente na relação da Galiza com o Minho. Esta última região surge em termos decorativos estimulada pela escultura galega, com destaque para a Catedral de Tui. Concordamos assim com Gerhard Graf, quando enuncia a forte influência da região espanhola no Minho ${ }^{117}$.

\footnotetext{
${ }^{115}$ REAL, Manuel Luís - op. cit., p. 44.

${ }^{116}$ GRAF, Gerhard - Portugal Roman. Yonne: Zodiaque, 1986. Vol. I, p.90.

${ }^{117}$ Ibidem, p.25.
}

Medievalista online № 17 I Janeiro - Junho 2015 (C) IEM - Instituto de Estudos Medieva is 28 www2.fc sh.unl.pt/ ie m/me die va lista 
Para além das sereias, figurações de mulheres e homens surgem com relativa frequência. No entanto, a sexualidade explícita não é visível na larga maioria dos casos, sendo uma prática contida. A maioria das representações eróticas são-no através dos significados simbólicos e não da representação plástica dos órgãos sexuais propriamente dita.

Ainda que a luxúria se encontre mais representada em modilhões, os capitéis surgem também correntemente como suportes utilizados para a sua aplicação. Por conseguinte, a visão de certos autores que consideram que os modilhões eram os preferidos para este tipo de representação devido a estarem mais distantes dos espaços considerados sagrados de uma igreja - ou seja, na periferia -, poderá não ser assim tão linear, pois encontramos representações em locais bem mais próximos do sagrado. Associado a este facto, a tese de haver uma maior liberdade artística dos escultores nos modilhões poderá também não ser tão segura, carecendo de maior investigação.

Embora se note que é uma temática secundária no estudo da escultura românica, este trabalho vem afirmar a necessidade de se avançar com mais estudos sobre o tema, porque o saber que chegou aos nossos dias pode estar enviesado devido à carência de uma análise mais objetiva e aprofundada.

\section{REFERÊNCIAS BIBLIOGRÁFICAS}

\section{Fontes impressas:}

A BÍBLIA Sagrada. Lisboa: Paulus Editora, 2009.

\section{Estudos:}

ALMEIDA, Carlos Aberto Ferreira de - História da arte em Portugal: o românico. Lisboa: Publicações Alfa, 1986.

- História da arte em Portugal: o românico. Lisboa: Editorial Presença, 2001.

- "Primeiras impressões sobre a arquitectura românica portuguesa". in Revista da Faculdade de Letras: História. Porto: Universidade do Porto / Faculdade de Letras. Série I, vol. 2 (1971), pp. 65-116. 
ALVES, Lourenço - "Igrejas e Capelas românicas da Ribeira Lima". in Caminiana. No 7, ano IV (1982), pp. 47-118.

AZEVEDO, Cândido de - Igreja românica de Sernancelhe. Sernancelhe: Câmara Municipal de Sernancelhe, 2012.

BARREIRA, Catarina Alexandra Martins Fernandes - Gárgulas: representações do feio e do grotesco no contexto português: séculos XIII a XVI [Em linha]. Lisboa: Universidade de Lisboa - Faculdade de Belas Artes, 2010. Tese de doutoramento em

Belas Artes. [Consultado a 08.11.2013]. Disponível em: http://repositorio.ul.pt/handle/10451/2590.

BOTELHO, Maria Leonor - A historiografia da arquitectura da época românica em Portugal: 1870-2010. Lisboa: FCG/FCT, 2013.

- "Mosteiro de Roriz". in NUÑO GONZÁLEZ, Jaime (coord.) - Arte românica em Portugal. Madrid: Fundación Santa María La Real, 2010, pp. 245-256.

- "Mosteiro de São Salvador de Bravães". in NUÑO GONZÁLEZ, Jaime (coord.) Arte românica em Portugal. Madrid: Fundación Santa María La Real, 2010, pp. 183198.

CAMILLE, Michael - Images dans les marges: aux limites de l'art médiéval. Paris: Gallimard, 1997.

FERNANDES, Paulo Almeida - "A escultura românica em Portugal: construções historiográficas e desafios actuais". in COLÓQUIO INTERNACIONAL DE HISTÓRIA DE ARTE - A escultura em Portugal da Idade Média ao início da Idade Contemporânea: história e património. Lisboa: Fundação das Casas da Fronteira e de Alorna, 2009, pp. 25-54.

- "Iconografia do apocalipse: uma nova leitura do portal ocidental da Sé de Lisboa". in Estudos Património. Lisboa: IPPAR. № 7 (2004), pp. 93-101.

GRAF, Gerhard - Portugal Roman. Vol. I. Yonne: Zodiaque, 1986.

IGESPAR - "Igreja matriz de Alcácer do Sal" [Em linha]. Lisboa: Igespar. [Consultado a 19.06.2014]. Disponível em: http://www.igespar.pt/pt/patrimonio/pesquisa/geral/patrimonioimovel/detail/74821/. 
LEÓN GÓMEZ, Carmelo - "Rutas por el Románico de la comarca: el románico erótico". in Arevagos [Em linha]. El Burgo de Osma: Aprodebur, 2005 - 2010. No 40 (2010) [Consultado a 08.11.2013]. Disponível em: http://www.islabahia.com/aprodebur/Arevacos/40_enero2010/40romanico.htm.

LIMA, Alexandra Cerveira Pinto S. (coord.) - Terras do Côa: da Malcata ao Reboredo [Em linha]. Guarda: Estrela-Côa, 1998. [Consultado a 09.10.2013]. Disponível em: http://www.arte-coa.pt/Ficheiros/Bibliografia/1686/1686.pt.pdf.

LOIS GARCÍA, Xosé - Simbologia do românico de Amarante. Amarante: Edições do Tâmega, 1990.

LOPES, Hugo - "Os mosteiros medievais como edifícios de saber: A conquista do território pela implantação de conhecimento desde o século X ao século XII - O caso português como ilustração paradigmática". in Millenium: Revista do ISPV [Em linha]. Ano 8, $\mathrm{n}^{\mathrm{o}} 27$ (Abr. 2003), pp. 138-194. [Consultado a 08.11.2013]. Disponível em http://www.ipv.pt/millenium/Millenium27/20.htm.

LOPES, Roger Teixeira - Carrazeda de Ansiães: património artístico. Mirandela: João Azevedo Editor, 1996.

MARQUES, Marisa Costa - "O mundo do fantástico na arte românica e gótica em Portugal: o género diplomático 'notícia' na documentação medieval portuguesa (séculos X-XIII). Dissertação de mestrado em História da Arte, apresentada à Faculdade de Ciências Sociais e Humanas da Universidade Nova de Lisboa em Julho de 2007". in Medievalista [Em linha]. No 8 (Jul. de 2010). [Consultado a 08.11.2013]. Disponível em http://www2.fcsh.unl.pt/iem/medievalista/MEDIEVALISTA8\marques8013.html.

MARTÍN JIMÉNEZ, Carlos M. - Las mejores rutas por el románico de Palencia. Palencia: Deputación de Palencia, 2008.

MARTINS, Fausto Sanches - "As imagens das nossas igrejas". in CONGRESSO SOBRE A DIOCESE DO PORTO, I, 2002 - Tempos e lugares de memória: actas. Porto/Arouca: UC/FLUP, 2002. Vol.I, pp. 211-221.

MATTOSO, José (dir.) - XVII Exposição Europeia de Arte, Ciência e Cultura: Os Descobrimentos Portugueses e a Europa do Renascimento. Convento da Madre de Deus: Os Antecedentes Medievais dos Descobrimento. Lisboa: Imprensa Nacional-Casa da Moeda, 1983.

Medievalista online № 17 I Janeiro - Junho 2015 ( $\mathbb{E M}$ - Instituto de Estudos Medieva is 31 www2.fc sh.unl.pt/ie m/me die va lista 
- "O corpo, a saúde e a doença". in MATTOSO, José (dir.) - História da vida privada em Portugal: a Idade Média. Vol. I. Lisboa: Temas e Debates, 2011, pp. 348-374.

NOÉ, Paula - "Capela de Santo Abdão". in Monumentos.pt [Em linha]. Sacavém: IHRU, 1992. [Consultado a 08.11.2013]. Disponível em: http://www.monumentos.pt/Site/APP_PagesUser/SIPA.aspx?id=2106.

NUÑO, Jaime - "Erotismo medieval: sexo y arte románico". in Agenda de Reflexion [Em linha]. No 794 (Mar. 2012). [Consultado a 10.12.2013]. Disponível em: http://www.agendadereflexion.com.ar/2012/03/20/794-erotismo medieval-sexo-y-arteromanico/.

OLIVEIRA, A. de Sousa - "Temas psicomáquicos na escultura românica decorativa". in Lucerna. Vol. V (1966), pp. 655-663.

OLIVEIRA, António Resende de - "A sexualidade". in MATTOSO, José (dir.) História da vida privada em Portugal: a Idade Média. Vol. I. Lisboa: Temas e Debates, 2011, pp. 324-347.

PACAUT, Marcel - "A Europa românica ou o tempo das primeiras sementeiras". In

GRIMAL, Pierre et al. - História geral da Europa. Vol. 1. Mem Martins: Publicções Europa-América, 1996, pp. 355-440.

REAL, Manuel Luís - "La sculpture figurative dans l'art roman du Portugal". in GRAF, Gerhard - Portugal Roman. Vol. I. Yonne: Zodiaque, 1986, pp. 33-75.

RÉAU, Louis - Iconografía del arte cristiano: introducción general. Vol. 3. Barcelona: Ediciones del Serbal, 2008.

- Iconografía del arte cristiano: iconografía de la Biblia: Nuevo Testamento. Barcelona: Ediciones del Serbal, 2008.

RODRIGUES, Jorge - "A escultura românica". in PEREIRA, Paulo - História da arte portuguesa. Vol. 1. Lisboa: Círculo de Leitores, 1995, pp. 264-331.

- Galilea, Locus e Memória: panteões, estruturas funerárias e espaços religiosos associados em Portugal... Lisboa: Universidade Nova de Lisboa, Tese de doutoramento em História da Arte, 2011.

- "O mundo românico: século XI-XIII". in PEREIRA, Paulo - História da arte portuguesa. Vol. 2. Lisboa: Círculo de Leitores, 1995, pp. 9-157. 
ROSAS, Lúcia - "A análise crítica". in SANTOS, Maria José Ferreira dos (coord.) Igreja de S. Pedro de Abragão: redescobrir um templo românico. Penafiel: Museu Municipal de Penafiel, 2008, pp. 23-33.

- "Igreja de São Tiago de Adeganha". in NUÑO GONZÁLEZ, Jaime - Arte românica em Portugal. Madrid: Fundación Santa María La Real, 2010, pp. 285-296.

ROSAS, Lúcia (coord.) - Românico do Vale do Sousa. Lousada: VALSOUSA, 2008.

ROSAS, Lúcia; BOTELHO, Leonor; RESENDE, Nuno - Rota do Românico. Vol. II. Lousada: Centro de Estudos do Românico e do Território, 2014.

ROTA DO ROMÂNICO - "Igreja de Santa Maria Maior de Tarouquela". in Rota do Românico [Em linha]. Lousada: Rota do Românico, 2013. [Consultado a 10.12.2013]. Disponível em: http://www.rotadoromanico.com/vPT/Monumentos.

SERNA, Andrés - El romanico erotico: lujuria en los templos cristianos [Em linha]. S.l.: s.n., 2012. [Consultado a 11.12.2013]. Disponível em: http://elcorreodelasmatas.blogspot.com.es/2012/12/el-romanico-erotico-lujuria-enlos.html.

SERRANO, Ferran Salgado - "La colegiata de San pedro de Cervatos". in Revista Arqueología, historia y viajes sobre el mundo medieval. No 44 (2012), pp. 52-61.

SILVA, João Ribeiro da - "Elementos românicos da Igreja de Rosém". in MARCO HISTÓRICO E CULTURAL - Atas de eventos marcoenses: 1988-1998. Marco de Canaveses: Câmara Municipal do Marco de Canaveses, 1998, pp. 151-156.

SOUSA, Luís Correia de - "Iconografia musical na escultura Românica em Portugal". in Medievalista [Em linha]. № 1, ano 1 (2005). [Consultado a 11.12.2013]. Disponível em: $\quad$ http://www2.fcsh.unl.pt/iem/medievalista/MEDIEVALISTA1/medievalistaiconografia.htm.

SOUZA, Armênia Maria - "A realeza cristã ibérica no Espelho dos reis de frei Álvaro Pais (séc. XIV)". in Dimensões. Vol. 26 (2011), pp. 189-215.

VALLE, Carlos - Revista de Etnografia, Tradições Populares de Vila Nova de Gaia. Porto: Junta Distrital do Porto, 1965.

VASCONCELOS, Joaquim; ABREU, Marques - Arte românica em Portugal. Lisboa: Publicações Dom Quixote, 1919. 
VERMEERSCH, Paula Ferreira - "Considerações sobre representações fantásticas em capitéis românicos". in Unicamp - Instituto de Estudos da Linguagem [Em linha]. (1998).
[Consultado
a
22.12.2013].
Disponível
em:

http://www.unicamp.br/iel/site/alunos/publicacoes/textos/c00016.htm.

\section{COMO CITAR ESTE ARTIGO}

\section{Referência electrónica:}

COSTA, Joaquim Luís - "Luxúria e iconografia na escultura românica portuguesa".

Medievalista [Em linha]. No 17 (Janeiro - Junho 2015). [Consultado 01.01.2015].

Disponível em http://www2.fcsh.unl.pt/iem/medievalista/MEDIEVALISTA17/ joaquimcosta1705.html

ISSN 1646-740X.

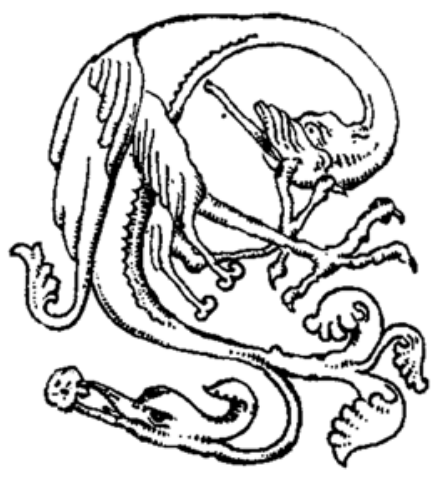

